\section{Diagnosis delay of Duchenne Muscular Dystrophy}

\section{Demora no diagnóstico da Distrofia Muscular de Duchenne}

Alexandra Prufer de Queiroz Campos Araújo 1 Mariana Castro de Deco 2

Beatriz de Sá Klôh 3

Mariana Rangel da Costa 4

Fernanda Veiga de Góis 5

Ana Flavia Chaves Mendonça Guimarães 6

1 Instituto de Puericultura e Pediatria Martagão Gesteira. Departamento de Pediatria. Serviço de Neuropediatria. Universidade Federal do Rio de Janeiro. Avenida Brigadeiro Trompowski s. n. Ilha do Fundão. Rio de Janeiro, RJ. Brasil. CEP: 21.941-590 E-mail: alexprufer@ufrj.br

2-4 Programa de Iniciação Científica. Faculdade de Medicina. Universidade Federal do Rio de Janeiro, Rio de Janeiro, RJ, Brasil 5,6 Pós-graduação em Neuropediatria. Universidade Federal do Rio de Janeiro, RJ, Brasil.

\section{Resumo}

Objetivos: estudar as características clínicas da

Objectives: to study the clinical features of Duchenne Muscular Dystrophy with emphasis on diagnosis delay.

Methods: an observational descriptive retrospective study was performed using medical records of patients with diagnosis of Duchenne Muscular Dystrophy given in the period from 1989 to 2000 at the neuropediatric out-patient clinic of a University Hospital.

Results: immunohistochemical results or deletion on the dystrophin gene confirmed the diagnosis of the 78 boys included in this study. Parents had noticed the first symptoms since the median age of two years. The final diagnosis was reached at a median age of seven.

Conclusions: diagnosis age is closer to the age of ambulation loss than that of the first symptoms. There is a marked delay for the diagnosis of this disease in our setting.

Key words Muscular Dystrophy Duchenne, Diagnosis, Age factors
Distrofia Muscular de Duchenne, com especial enfoque no tempo decorrido para o diagnóstico.

Métodos: realizou-se um estudo observacional descritivo e retrospectivo de pacientes com diagnóstico de distrofia muscular atendidos nos ambulatórios de neuropediatria de um Hospital Universitário no período de 1989 a 2000.

Resultados: foram incluídos 78 meninos com confirmação diagnóstica por imunohistoquímica ou deleção no gene da distrofina. A idade mediana da percepção dos primeiros sintomas pela família foi de dois anos e a idade mediana do diagnóstico definitivo de sete anos.

Conclusões: a época do diagnóstico se aproxima mais da idade da perda da marcha do que do início dos sintomas. É grande a demora para o diagnóstico desta doença em nosso meio.

Palavras-chave Distrofia Muscular de Duchenne, Diagnóstico, Fatores etários 


\section{Introduction}

Duchenne Muscular Dystrophy (DMD) is the most common hereditary neuromuscular disorder in the first two decades of life. As an X-linked disease it affects boys regardless ethnic or racial origin. Population studies, in different countries and time, indicate an incidence of 25:100,000 live males births per year. ${ }^{1-3}$ Tip toe and waddling gait, pelvic girdle weakness, frequent falls and calf enlargement are characteristic of this progressive disease. It evolves with weakness of other muscular groups, and after loss of deambulation, respiratory failure and death occurs, generally by the end of the second decade of live.

Confirmation of DMD depends on diagnostic tests: absent dystrophin on muscular biopsy or presence of a deletion in the dystrophin gene located on chromosome Xp21.4 One should be suspicious of DMD when creatine phosphokinase (CK) are elevated in boys with developmental delay or in neonatal screening procedures. 5

There is no current curative treatment for the disease. Steroids may modify the natural course. 6-9 An $^{-9}$ improvement in muscle strength has been demonstrated during the first three months of its use as well as prolongation of independent ambulation on follow up. ${ }^{7}$ Motor and respiratory physiotherapy are indicated to prevent complications and to improve quality of life in DMD boys.

Early diagnosis is possible, $5,10,11$ allows a realistic family planning, and influences prognosis through earlier management. 12

The knowledge of the natural history of DMD in Brazil is scarce. The aim of this study is to describe the clinical features of DMD patients followed during the last decade, with emphases on the time taken for definite diagnosis.

\section{Methods}

This is a retrospective descriptive observational study. Data was collected from hospital files of 107 patients with a clinical diagnosis of DMD, from the neuropediatric out-patient clinic of the Institute of Pediatrics (IPPMG) from the Federal University of Rio de Janeiro (UFRJ), RJ, Brazil, between 1989 and 2000. Needle muscle biopsy, imunohistochemical studies and deletion studies are available at the UFRJ. The neuropediatric out-patient clinic follows children referred by the pediatricians of the University as well as from other pediatric hospitals in the state of Rio de Janeiro.
Inclusion criteria were: confirmed DMD diagnosis by either deletion on Southern-blot or absence of dystrophin in muscle biopsy, and at least three appointments at the clinic.

The age of the first symptoms was considered as the one a family member first noticed some problem (developmental delay, falls); the age of diagnosis the one by the date of the confirmatory test (either muscle biopsy or molecular DNA method).

Data was collected on a specific form and were kept and analyzed using Excel.

This study has been approved by the Review Board of the Institute of Pediatrics of the Federal University of Rio de Janeiro, in October 29, 2001, and all norms of ethical national human research rules fulfilled.

\section{Results}

Among the 107 patients initially listed, 78 were confirmed as having DMD and included in this study. The mean age was 12.8 years (2-22) and two boys had already deceased. Diagnosis confirmation before the age of five years occurred in only seven boys, two of which (at 18 months and three years) due to other cases in the family. Overall there were 20 with a positive family history. Developmental delay (late onset walking) and walking difficulties were the first abnormalities recognized by family members. No global developmental delay had been noticed. The time taken from the age of those first abnormalities and the age of diagnostic confirmation was of five years. All boys had CK measured before the muscle biopsy or the search for deletion, and 13 had this test done before being consulted at our out-patient clinic. CK was elevated in all of them (on average 30x the upper normal limits). Electromyography done in 24 patients showed a pattern of typical but unspecific muscular involvement.

Out of frame deletions were detected in 22 boys. In the remaining the confirmation of the diagnosis derived from dystrophin absence in muscle biopsy immunostaining. Therefore these were all DMD cases.

The age of diagnosis was quite near the age those boys lost ambulation and far from the time the first abnormalities were noticed by family members (Table 1). The time taken for this diagnosis is greater than that found in other countries (Figure 1). 
General features of boys with Duchenne Muscular Dystrophy at the Institute of Pediatrics of the Federal University of Rio de Janeiro. Rio de Janeiro, 1989 through 2000.

\begin{tabular}{ll}
\hline Feature & \\
\hline Total suspicious diagnosis & 107 \\
Total included & 78 \\
Age of first symptoms (median) & 2 years [0.5 to 8] \\
Age of diagnosis (median) & 7 years [1.75 to 12] \\
Age of ambulation loss (median) & 9.5 years [ 6 to 13$]$ \\
Confirmation derived from deletion & $22 / 30(73 \%)$ \\
Treatment & \\
$\quad$ Physical therapy & $65 / 78(83 \%)$ \\
$\quad$ Steroid & $46 / 78(59 \%)$ \\
\hline
\end{tabular}

Figure 1

Time for diagnosis of Duchenne Muscular Dystrophy.

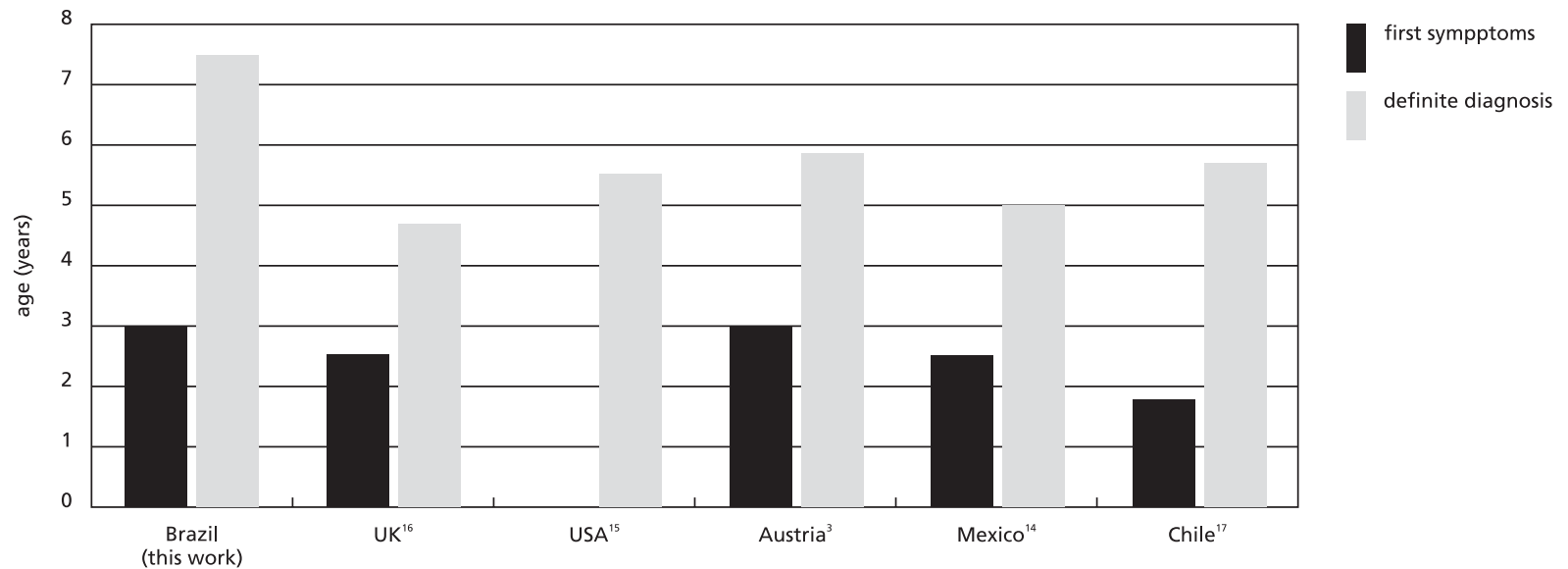

For the construction of Figure 1 means of age first symptoms (3.0 years) and of age of diagnosis confirmation (7,5 years) were used instead of median values, to compare with the data from other countries.

Age of final diagnosis was not different between those 27 seen for the first time up to 1995 when compared to the 51 seen after 1996. Equally, no difference was observed between the 22 confirmed by the presence of deletion and those that had the immunostaining as their final diagnosis.
By the time of the data collection nine patients, from four to 15 years, were still able to walk. Most had ongoing physical therapy. Steroids had been used in 46 boys. 


\section{Discussion}

There are no national epidemiological data on incidence or prevalence of DMD. Based on Brazilian demographic statistics 13 of male newborns and other countries incidence, one could estimate that more than 400 boys with DMD would have been born per year in Brazil since 1993, and more than 65 would have mothers that lived in Rio de Janeiro's state.

We have found a mean age of 7.5 years at definite diagnosis, which turn out to be two years later than that found in other countries, $3,14-17$ and already considered late by those authors. However, there was not a great difference at the mean age of detection of first abnormalities when compared among those studies.

Some countries have a neonatal screening program that includes CK levels, 3,5 but this is not the case in Brazil. Therefore, diagnosis must rely on the onset of the first symptoms or signs of the disease and CK levels in suspicious cases. High CK levels in boys with locomotor function delay, or tiptoe walking, or frequent falls after the beginning of walking are features that indicate this diagnosis possibility.

Family members may concern about walking delay, frequent falls or other walking problems. Many boys are referred to other health care professionals as having flat feet, delaying the diagnosis. Others have a global developmental delay, with speech and language delay being present as well. 18

The global developmental delay and the referral to other professionals are recognized reasons for the diagnosis delay.14,17 A pediatrician that follows carefully the developmental milestones should be warned that a neuromuscular disease may also be a cause of global developmental delay.

As we have defined for the purpose of the present study the beginning of the disease as being the age the parents first noticed an abnormality there might be a possibility of error. Health care professionals are trained to recognize minor signs while layman may only be aware of major ones. Probably the initial physical indications occur sooner than indicated by this study. Although we included only patients with DMD we had some families that only became aware of some problem when their child was becoming unable to walk.

In the UK most cases where not detected by family doctors, but referred by school teachers. 16 Nevertheless more than half began to walk after 18 months, an age at which diagnosis could be suspected if enzyme levels had been checked. ${ }^{11}$

Through the years, from 1989 to 2000, we could not observe an earlier age of diagnosis. More recent and less invasive tests, detection of deletion on blood samples, seem also not to have contributed in speeding the diagnosis. Confirmation of $73 \%$ of our DMD cases based on the presence of deletion is according to the literature. 4

The present study has shown it takes a long time for a diagnosis of DMD to be achieved. The reasons for this delay may rely on poor importance given to the early signs, referral to other specialists, difficult access to screening procedures, difficult access to centers where definite diagnostic could be offered. We probably have a problem of referral to the right health care professional. Only $16 \%$ of the patients had a CK test done before consultation with the neuropediatrician, which supports the failure to recognize the relation of the symptoms with this disease or a difficulty in the access to screening tests.

Confirmatory tests, immunostaining or molecular biology tests are available only in reference centers. This could justify the diagnosis delay. However, five years, from the time that first family concerns were apparent to final diagnosis, are far to much for this to be the only reason.

Late diagnosis holds up genetic counseling, contributing to the birth of other boys with DMD in the family, not giving the opportunity for prevention with family planning measures.

Treatment management, when started late, may not modify the functional ability and life quality of those patients. By the end of the 70th decade the effect of steroids on dystrophic muscles started to be published. 6 The effect in children became known a decade latter. ${ }^{7}$ Steroid treatment delays motor function loss, 8,9 and there might be a better therapeutic effect if it is started earlier.

Either general or specific treatment measures can only be started early if children with developmental problems are recognized and diagnosed in shorter period of time. We send all patients, even only with suspicious diagnosis, to physical therapy. After confirmation, if still ambulant and without contraindication, we start steroids. Access difficulties explains why some of our patients were not on physical therapy.

Boys with DMD are referred late, hampering attempts to maintain ambulation. DMD diagnosis may be suspected by general doctors or pediatricians. Asking for CK levels, a simple, quick and low cost test, in boys with developmental delay, frequent falls, running or jumping difficulties when compared to same age peers, may indicate the diagnosis. Those with high enzyme levels should be referred immediately to reference centers that offer the complete investigation.

Those steps could reduce the long time observed from first symptoms to final diagnosis. 


\section{References}

1. Nigro G, Comi LI, Limongelli FM, Giugliano MA, Politano L, Petretta V, Passamano L, Stefanelli S. Prospective study of X-linked progressive Muscular Dystrophy in Campania. Muscle Nerve 1983; 6: 253-62.

2. van Essen AJ, Busch HF, te Meerman GJ, ten Kate LP. Birth and population prevalence of Duchenne Muscular Dystrophy in The Netherlands. Hum Genet 1992; 88: 25866.

3. Hauser E, Toifl K, Mad A, Bittner R. The incidence of Duchenne Muscular Dystrophy in eastern Austria. The controversy regarding $\mathrm{CK}$ screening. Wien Klin Wochenschr 1993;105: 433-6.

4. van Essen AJ, Kneppers AL, van der Hout AH, Scheffer H, Ginjaar IB, ten Kate LP, van Ommen GJ, Buys CH, Bakker E. The clinical and molecular genetic approach to Duchenne and Becker Muscular Dystrophy: an updated protocol. J Med Genet 1997; 34: 805-12.

5. van Ommen GJ, Scheuerbrandt G. Neonatal screening for Muscular Dystrophy. Consensus recommendation of the 14th workshop sponsored by the European Neuromuscular Center (ENMC). Neuromuscul Disord 1993; 3: 231-9.

6. Cohen L, Morgan J, Bozyk ME. Variable effects of corticosteroid treatment of serum enzyme activities in Duchenne's Muscular Dystrophy. Res Commun Chem Pathol Pharmacol 1977; 17: 529-38.

7. Mendell JR, Moxley RT, Griggs RC, Brooke MH, Fenichel GM, Miller JP, King W, Signore L, Pandya S, Florence J, Schierbecker J, Robison J, Kaiser K, Mandel S, Arfken C, Gilder B. Randomized, double-blind six-month trial of prednisone in Duchenne's Muscular Dystrophy. New Engl J Med 1989; 320: 1592-97.

8. Dubowitz V, Kinali M, Main M, Mercuri E, Muntoni F. Remission of clinical signs in early Duchenne Muscular Dystrophy on intermittent low-dosage prednisolone therapy. Eur J Paediatr Neurol 2002; 6: 153-9.

9. Merlini L, Cicognani A, Malaspina E, Gennari M, Gnudi S, Talim B, Franzoni E. Early prednisone treatment in
Duchenne Muscular Dystrophy. Muscle Nerve 2003; 27: 222-7.

10. Guibaud P, Carrier HN, Plauchu H, Lauras B, Jolivet MJ, Robert JM. Early clinical and histopathological manifestations in 14 boys showing elevated serum creatinephosphokinase levels in their first year. J Genet Hum 1981; 29: 71-84.

11. Gardner-Medwin D, Bundey S, Green S. Early diagnosis of Duchenne Muscular Dystrophy. Lancet 1978; 1: 1102.

12. Smith RA, Sibert JR, Wallace SJ, Harper PS. Early diagnosis and secondary prevention of Duchenne Muscular Dystrophy. Arch Dis Child 1989; 64: 787-90.

13. IBGE (Instituto Brasileiro de Geografia e Estatística). Sistema IBGE de Recuperação Automática, Banco de Dados Agregados, Registro Civil, Nascidos Vivos. Disponível em: http://www.sidra.ibge.gov.br/ [4 jul 2003].

14. Alvarez Leal M, Morales Aguilera A, Perez Zuno JA, Segura Romero S, Quiroz Gongora MC, Paredes Garcia A. Relations between delayed diagnosis and forms of onset in Duchenne Muscular Dystrophy. Gac Med Mex 1994; 130: 459-64.

15. Boland BJ, Silbert PL, Groover RV, Wollan PC, Silverstein MD. Skeletal, cardiac, and smooth muscle failure in Duchenne Muscular Dystrophy. Pediatr Neurol 1996; 14: 7-12.

16. Bushby KM, Hill A, Steele JG. Failure of early diagnosis in symptomatic Duchenne Muscular Dystrophy. Lancet 1999; 353: 557-8.

17. De los Angeles Avaria M, Kleinsteuber K, Herrera L, Carvallo P. Delayed diagnosis of Duchenne Muscular Dystrophy in Chile. Rev Med Chil 1999; 127: 65-70.

18. Essex C, Roper H. Lesson of the week: late diagnosis of Duchenne's Muscular Dystrophy presenting as global developmental delay. BMJ 2001; 323: 37-8.

Recebido em 12 de novembro de 2003

Versão final reapresentada em 14 de janeiro de 2004

Aprovado em 13 de fevereiro de 2004 